\title{
EFEKTIVITAS PROGRAM PELATIHAN KETERAMPILAN BERBASIS MASYARAKAT (KK MISKIN) OLEH DINAS TENAGA KERJA DAN TRANSMIGRASI
}

\section{THE EFFECTIVENESS OF COMMUNITY (POOR FAMILY)-BASED SKILL TRAINING PROGRAM BY THE LOCAL OFFICE OF MANPOWER AND TRANSMIGRATION OF}

T W Kurnia1a, A Iskandar'1, D Hernawan' ${ }^{1}$

\author{
${ }^{1}$ Program Studi Administrasi Publik, Fakultas Ilmu Sosial Dan Ilmu Politik, Universitas Djuanda Bogor \\ Jl. Tol Ciawi No. 1, Kotak Pos 35 Ciawi, Bogor 16720. \\ a Korespondensi: Tantia Wulandari Kurnia, E-mail: Ktantiawulan@gmail.com \\ (Diterima: 16-12-2018; Ditelaah: 17-12-2018; Disetujui: 03-05-2019)
}

\begin{abstract}
Poverty alleviation is still the main problem faced by every region. Community-based skills training program (Poor Family) by the Office of Manpower and Transmigration of Bogor City is one of the efforts to overcome the problem of poverty. The purpose of this research is to know the effectiveness of giving training materials; explain the time of giving the training materials; analyze the training materials provided with the work they have in community-based skills training (Poor Family) by the Bogor City Manpower and Transmigration Office. This research uses qualitative method that is looking for meaning, understanding, understanding, verstehen about a phenomenon, event, and human life by directly and / or indirectly involved in the setting of research, conceptual and thorough. The results of this study show the effectiveness of the implementation of community-based skills training activities (Poor Family) based on pre-training, training, monitoring and evaluation stage; the link between skills training and current work. The conclusion of this study suggests that community-based skills training activities (Poor Family) by Disnakertrans are quite effective.
\end{abstract}

Keywords: Program effectiveness, poor family, poverty alleviation, skill training.

\begin{abstract}
ABSTRAK
Pengentasan kemiskinan masih menjadi permasalahan utama yang saat ini dihadapi oleh setiap daerah. Program kegiatan pelatihan keterampilan berbasis masyarakat (KK Miskin) oleh Dinas Tenaga Kerja dan Transmigrasi Kota Bogor adalah salah satu upaya dalam mengatasi masalah kemiskinan. Tujuan dari penelitian ini adalah untuk mengetahui efektivitas pemberian materi pelatihan; menjelaskan waktu pemberian materi pelatihan; menganalisis materi pelatihan yang diberikan dengan pekerjaan yang dimiliki pada pelatihan keterampilan berbasis masyarakat (KK Miskin) oleh Dinas Tenaga Kerja dan Transmigrasi Kota Bogor. Penelitian ini menggunakan metode kualitatif yaitu mencari makna, pemahaman, pengertian, verstehen tentang suatu fenomena, kejadian, maupun kehidupan manusia dengan terlibat langsung dan atau tidak langsung dalam setting yang diteliti, konseptual dan menyeluruh. Hasil penelitian ini menunjukkan efektivitas pelaksanaan kegiatan pelatihan keterampilan berbasis masyarakat (KK Miskin) berdasarkan tahap pra pelatihan, pelatihan, monitoring dan evaluasi; keterkaitan antara pelatihan keterampilan dengan pekerjaan saat ini. Kesimpulan dari penelitian ini menyatakan bahwa kegiatan pelatihan keterampilan berbasis masyarakat (KK Miskin) oleh Disnakertrans cukup efektif.
\end{abstract}

Kata Kunci : Efektivitas program, keluarga miskin, pengentasan kemiskinan, pelatihan keterampilan.

Kurnia, T, K., Iskandar, A., \& Hernawan, D. (2019). Efektifitas Program Pelatihan keterampilan Berbasis Masyarakat (KK Miskin) Oleh Dinas Tenaga Kerja Dan Transmigrasi . Jurnal Sosial Humaniora, 10(1), $1-10$. 


\section{PENDAHULUAN}

Sustainable Depelovment Goals (SDGs) atau tujuan pembangunan berkelanjutan adalah kelanjutan sekaligus perbaikan dari program the Millenium Development Goals (MDGs) yang berakhir pada tahun 2015. Manusia sebagai salah satu pondasi SDGs tentunya memiliki peran yang penting dalam menyukseskan SDGs. Tujuan yang pertama dalam SDGs di Indonesia adalah no poverty atau pengentasan kemiskinan dengan 7 target yang intinya: pengentasan kemiskinan tahun 2030, memastikan perlindungan sosial bagi masyarakat miskin, dan meningkatkan akses layanan mendasar bagi masyarakat.

Berdasarkan data yang di dapat dari Kota Bogor dalam angka 2017, diketahui bahwa penduduk Kota Bogor pada tahun 2016 terdapat sebanyak 1.064.687 orang yang terdiri atas 540.288 orang laki-laki dan sebanyak 524.399 orang perempuan. Dengan tingkat kesejahteraan penduduk sebagai berikut:

Table 1. Tingkat kesejahteraan Penduduk Kota Bogor Tahun 2016.

\begin{tabular}{|c|c|c|c|c|c|c|c|c|}
\hline \multirow{3}{*}{ No. } & \multirow{3}{*}{ Kecamatan } & \multicolumn{7}{|c|}{ Tingkat Kesejahteraan } \\
\hline & & \multicolumn{2}{|c|}{ Pra KS } & \multicolumn{2}{|c|}{ KS1 } & \multirow{2}{*}{$\mathrm{KS} 2$} & \multirow{2}{*}{$\mathrm{KS} 3$} & \multirow{2}{*}{ KS3 Plus } \\
\hline & & Kkl & Jiwa & Kel & Jiwa & & & \\
\hline 1. & Bogor Timur & 881 & 3.563 & 5.544 & 22.228 & 9.812 & 4.533 & 1.952 \\
\hline 2. & Bogor Barat & 298 & 1.022 & 12.362 & 49.668 & 22.198 & 15.999 & 4.229 \\
\hline 3. & Bogor Selatan & 3.201 & 12.904 & 8.221 & 32.899 & 16.921 & 9.444 & 3.341 \\
\hline 4. & Bogor Tengah & 1.972 & 6.311 & 6.072 & 24.298 & 10.612 & 5.814 & 1.677 \\
\hline 5. & Tanah Sareal & 1.771 & 5.782 & 7.896 & 32.440 & 24.935 & 9.970 & 4.229 \\
\hline 6. & Bogor Utara & 1.254 & 4.016 & 6.966 & 28.022 & 14.992 & 11.677 & 3.392 \\
\hline & Jumlah & 9.377 & 33.598 & 47.061 & 189.555 & 99.470 & 57.437 & 18.820 \\
\hline
\end{tabular}

Sumber : Badan Pemberdayaan Masyarakat dan KB Kota Bogor.

Dinas tenaga kerja, sosial dan transmigrasi Kota Bogor memiliki tugas pokok berupa melaksanakan sebagian urusan pemerintah daerah di bidang tenaga kerja, sosial dan transmigrasi dengan mengacu kepada Peraturan Walikota Nomor 37 Tahun 2010 Tentang Tugas Pokok, Fungsi, Tata Kerja dan Uraian Tugas Jabatan Struktural di Lingkungan Dinas Tenaga Kerja, Sosial dan Transmigrasi Kota Bogor. Salah satu program kegiatan yang diselenggarakan oleh Dinas Tenaga Kerja, Sosial dan Transmigrasi adalah Peningkatan Kualitas dan Produktivitas Tenaga Kerja. Dalam program ini salah satunya adalah kegiatan pelatihan keterampilan berbasis masyarakat (KK miskin).
Kegiatan pelatihan keterampilan berbasis masyarakat (KK miskin) dimulai pada tahun 2015 dan masih terus berjalan hingga saat ini. Kegiatan ini tentunya diharapkan mampu membantu memecahkan masalah kemiskinan dengan diberikannya keterampilan pada peserta.

Dalam pelaksanaannya Dinas Tenaga Kerja, Sosial dan Transmigrasi Kota Bogor yang saat ini telah berubah nama menjadi Dinas Tenaga Kerja dan Transmigrasi Kota Bogor memiliki peran penting dalam membekali peserta pelatihan keterampilan sehingga nantinya dapat menambah wawasan serta membuka peluang dalam menambah penghasilan bagi peserta yang mengikuti pelatihan keterampilan.

Berdasarkan data yang di dapatkan dari Dinas Tenaga kerja dan Transmigrasi Kota Bogor Tahun 2017 diketahui bahwa kegiatan pelatihan keterampilan terbagi menjadi tiga, yakni pelatihan keterampilan tata rias, potong rambut dan pembuatan souvenir dari kain perca.

Kegiatan pelatihan keterampilan tersebut dilaksanakan disetiap masing-masing kelurahan. Pelaksanaan kegiatan pelatihan keterampilan ini tentunya sedikit banyak dapat memberikan peluang bagi peserta dalam menambah penghasilannya apabila berjalan dengan efektif. Sehingga dapat menjadi salah satu upaya dari pengentasan kemiskinan. Adapun rincian datanya adalah sebagai berikut: 
Tabel 2. Jadwal Kegiatan Pelatihan Keterampilan Berbasis Masyarakat (KK Miskin).

\begin{tabular}{|c|c|c|c|c|c|c|c|}
\hline No. & Lokasi & Jenis Kegiatan & Jumlah Peserta & Lama Pelatihan & Rencana Pelaksanaan & Persyaratan & Pengajar \\
\hline 1. & $\begin{array}{c}\text { Kelurahan Tajur dan } \\
\text { Sukasari }\end{array}$ & $\begin{array}{c}\text { Pelatihan Potong Rambut } \\
\text { Barbershop }\end{array}$ & 10 Orang & 3 Hari & $\begin{array}{l}\text { Vinggu III } \\
\text { Bulan Juli }\end{array}$ & $\begin{array}{l}\text { 1. Ft. copy KTP } \\
\text { 2. Ft. copy Tanda } \\
\text { Register KK .Viskin } \\
\text { 3. Lsia Produktif } \\
\text { 4. Laki-laki }\end{array}$ & Bemy Valentine \\
\hline 2 & $\begin{array}{l}\text { Kelurahan Pasir Jaya } \\
\text { (P2IIKSS) }\end{array}$ & Pelathan Tata Rias Wajah & 10 Orang & 6 Hari & $\begin{array}{l}\text { Minggu III } \\
\text { Bulan Agustus }\end{array}$ & $\begin{array}{l}\text { 1. Ft. copy KTP } \\
\text { 2. Ft Copy Tanda } \\
\text { Register KK.Viskin } \\
\text { 3. Lsia Produktif } \\
\text { 4. Perempuan }\end{array}$ & LPK John Yan Tien \\
\hline 3. & $\begin{array}{c}\text { Kampung .Muara } \\
\text { Kelurahan Pasir Jaỵa }\end{array}$ & $\begin{array}{c}\text { Pelatihan Potong Rambut } \\
\text { Barbersbop }\end{array}$ & 10 Orang & 7 Hari & $\begin{array}{c}\text { Yinggu IV' } \\
\text { Bulan Agustus }\end{array}$ & $\begin{array}{l}\text { 1. Ft. copy KIP } \\
\text { 2. Ft. copy Tanda } \\
\text { Register KK. .Viskin } \\
\text { 3. Usia Produktif } \\
\text { 4. Laki-laki }\end{array}$ & LPK John Yan Tien \\
\hline 4. & Kehrahan Tegal Gundil & $\begin{array}{l}\text { Pelatihan Potong Rambut } \\
\text { Barbershop }\end{array}$ & 10 Orang & 7 Hari & $\begin{array}{c}\text { Minggu III } \\
\text { Bulan September }\end{array}$ & $\begin{array}{l}\text { 1. Ft. copy KTP } \\
\text { 2. Ft. copy Tanda } \\
\text { Register KK .Miskin } \\
\text { 3. L'sia Produktif } \\
\text { 4. Labi-laki }\end{array}$ & LPK John Van Tien \\
\hline$\leq$ & Kehurahan Cibuluh & $\begin{array}{c}\text { Pelatihan Sorvenir dari } \\
\text { Kain Perca }\end{array}$ & 10 Orang & 6 hari & $\begin{array}{c}\text { Minggu IV } \\
\text { Bulan September }\end{array}$ & $\begin{array}{l}\text { 1. Ft. copy KTP } \\
\text { 2. Ft. copy Tanda } \\
\text { Register KK Miskin } \\
\text { 3. } 17 \text { s.d } 50 \text { Tahun } \\
\text { 4. Perempuan }\end{array}$ & LPK Batik Pancawati \\
\hline 6. & Kehurahan Bojongkerta & Pelatihan Souvenir & 10 Orang & + Hari & $\begin{array}{c}\text { Minggu III } \\
\text { Bulan Oktober }\end{array}$ & $\begin{array}{l}\text { 1. Ft. copy KIP } \\
\text { 2. Ft. copy Ianda } \\
\text { Register KK . Miskin } \\
\text { 3. } 17 \text { s.d } 50 \text { Tahus } \\
\text { 4. Perempuan }\end{array}$ & LPK Ratih \\
\hline 7 & Kehsahan Rancanlaya & Pelatihan Sourienir & 10 Orang & 4 Hari & $\begin{array}{l}\text { Minggu IV } \\
\text { Bulan Oktober }\end{array}$ & $\begin{array}{l}\text { 1. Ft. copy KIP } \\
\text { 2. Ft. copy Tanda } \\
\text { Register KK Miskin } \\
\text { 3. } 17 \text { s } 50 \text { Tahun } \\
\text { 4 Perempuan }\end{array}$ & LPK Rath \\
\hline
\end{tabular}

Sumber : Dinas Tenaga Kerja dan Transmigrasi Kota Bogor

Berdasarkan pemaparan di atas peneliti tertarik untuk meneliti tentang Efektivitas Kegiatan Pelatihan Keterampilan Berbasis Mayarakat (KK Miskin) Tahun 2017 oleh Dinas Tenaga Kerja dan Transmigrasi Kota Bogor.

\section{MATERI DAN METODE}

\section{Teori yang Relevan}

Pada penelitian ini, penulis menggunakan beberapa teori yang terdiri dari:

\section{Pelatihan Keterampilan}

Dalam (Budi Santoso, 2013), pelatihan adalah kegiatan yang dilakukan untuk meningkatkan pengetahuan, keterampilan, kinerja, dan perilaku individu, kelompok maupun organisasi. Oleh karena itu kegiatan pelatihan harus dirancang sedemikian rupa agar benar-benar memberikan manfaat sesuai tujuan pelaksanaannya. Dari segi materi, pelatihan dapat digolongkan menjadi dua jenis, yaitu; Pelatihan Wacana (Knowledge Based Training) Adalah sebuah pelatihan mengenai sebuah wacana baru yang harus disosialisasikan kepada peserta pelatihan dengan tujuan wacana baru tersebut dapat meningkatkan pencapaian tujuan seseorang, kelompok, organisasi atau lembaga. Pelatihan Keterampilan (Skill Based Training) Adalah sebuah pelatihan mengenai pengenalan atau pemdalaman keterampilan seseorang, kelompok, oraganisasi atau lembaga baik secara teknis (Hard Skill) maupun bersifat non teknis yang lebih bersifat pada pengembangan pribadi (Soft Skill).

\section{Kemiskinan}

Adapun penduduk miskin menurut BPS adalah penduduk yang memiliki rata-rata pengeluaran 
perkapita perbulan dibawah garis kemiskinan. Menurut (website resmi BPS, 2018) dalam mengukur kemiskinan dapat digunakan konsep kemampuan memenuhi kebutuhan dasar (basic needs approach). Dengan pendekatan ini, kemiskinan dipandang sebagai ketidak mampuan dari sisi ekonomi untuk memenuhi kebutuhan dasar makanan dan bukan makanan yang diukur dari sisi pengeluaran. Garis kemiskinan itu sendiri merupakan penjumlahan dari Garis Kemiskinan Makanan (GKM) dan Garis Kemiskinan Non Makanan (GKNM). Garis kemiskinan untuk Kota Bogor pada tahun 2017 adalah Rp 450.078 Jadi penduduk yang memiliki rata-rata pengeluaran perkapita perbulan dibawah Garis Kemiskinan tersebut dapat dikategorikan sebagai penduduk miskin.

\section{Efektivitas Organisasi}

Menurut (Stoner,1982) dalam (Hassel, 2005) menekankan pentingnya efektivitas organisasi dalam pencapaian tujuan-tujuan organisasi, dan efektivitas adalah kunci kesuksesan suatu organisasi. Disimpulkan bahwa konsep tingkat efektivitas organisasi menunjuk pada tingkat sejauh mana organisasi melaksanakan kegiatan atau fungsi-fungsi sehingga tujuan yang telah ditetapkan dapat tercapai dengan menggunakan secara optimal alat-alat dan sumber-sumber yang ada. Ini berarti bahwa pembicaraan mengenai efektivitas organisasi menyangkut dua aspek, yaitu: Tujuan organisasi, dan Pelaksanaan fungsi atau cara untuk mencapai tujuan tersebut.

Dalam analisis ini, perspektif efektivitas organisasi yang digunakan adalah perspektif tujuan, dimana tolak ukur yang digunakan adalah bagaimana organisasi mencai tujuan, termasuk merealisasi visi dan misi organisasi sesuai dengan mandat yang diembannya.

\section{Kerangka Pemikiran}

Menurut (Uma Sekaran,1992) dalam (Sugiyono, 2010) mengemukakan bahwa, kerangka berfikir merupakan model konseptual tentang bagaimana teori berhubungan dengan berbagai faktor yang telah diidentifikasi sebagai masalah penting.

Pelatihan keterampilan berbasis masyarakat (KK miskin) yang dilaksanakan oleh Dinas Tenaga Kerja dan Transmigrasi Kota Bogor merupakan salah satu upaya penanggulangan kemiskinan. Dimana kegiatan yang dilakukan adalah dengan memberikan pelatihan keterampilan berupa potong rambut, tata rias dan pembuatan souvenir dari kain perca.
Kegiatan pelatihan keterampilan ini ditujukan hanya untuk masyarakat miskin yang memiliki keinginan untuk mendapatkan dan menambah keterampilan dan keahlian yang dimiliki. Dimana hasil akhir dari pelatihan ini adalah dapat menciptakan peserta pelatihan yang terampil dan produktif sehingga dapat menambah penghasilan peserta pelatihan.

Untuk mempermudah dan mengetahui bagaimana model konseptual dari penelitian ini adalah sebagai berikut:

Gambar 1. Kerangka Pemikiran

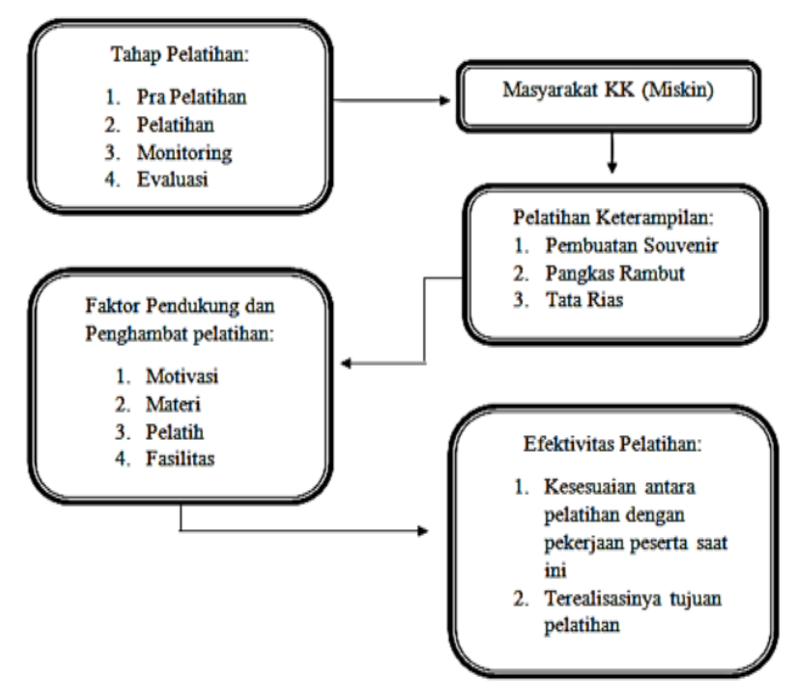

Sumber: Peneliti tahun 2018

\section{Pendekatan dan Metode Penelitian}

Pendekatan penelitian yang digunakan oleh peneliti adalah penelitian kualitatif. Menurut (Muri Yusuf, 2017) penelitian kualitatif adalah mencari makna, pemahaman, pengertian, verstehen tentang suatu fenomena, kejadian, maupun kehidupan manusia dengan terlibat langsung dan atau tidak langsung dalam setting yang diteliti, konseptual dan menyeluruh.

Sedangkan metode penelitian yang digunakan adalah deskriptif kualitatif . Dalam penelitian deskriptif terdapat rumusan masalah yang berkenaan dengan pertanyaan terhadap keberadaan variabel mandiri dan dalam penelitian ini peneliti tidak membuat perbandingan variabel pada sampel yang lain atau mencari hubungan satu variabel dengan variabel lainnya (Sugiyono, 2013). Data dalam penelitian kualitatif adalah data deskriptif yang umumnya berbentuk kata-kata, gambar-gambar, atau rekaman. Dimana tujuan awal dalam penelitian ini adalah menjelaskan mengenai efektivitas kegiatan pelatihan keterampilan berbasis masyarakat (KK miskin) tahun 2017 
oleh Dinas Tenaga Kerja dan Transmigrasi Kota Bogor.

\section{Informan}

Menurut (Moleong, 2010) dalam buku Metode Penelitian Kualitatif, Informan adalah orang yang dimanfaatkan untuk memberikan informasi tentang situasi dan kondisi latar belakang penelitian. Adapun yang menjadi informan dalam penelitian ini berjumlah 18 orang, yaitu: KASI Pelatihan dan Kelembagaan Pelatihan Dinas Tenaga Kerja dan Transmigrasi Kota Bogor sebanyak 1 orang; KASI atau Staf Kelurahankelurahan selaku pelaksana program sebanyak 7 orang; Instruktur pelatihan sebanyak 1 orang; Peserta pelatihan keterampilan sebanyak 9 orang.

\section{Teknik Pengumpulan data}

Dalam Eko sugiarto tahun 2017 pengumpulan data dilakukan pada kondisi yang alamiah karena menurut (Creswell, 2012) konteks natural inilah yang menjadi karakteristik utama penelitian kualitatif. Peran peneliti adalah sebagai instrumen kunci yang mengumpulkan data sendiri. Secara umum ada empat macam teknik pengumpulan data yaitu teknik observasi, wawancara, dokumentasi dan gabungan/ triangulasi (Sugiyono, 2013).

Observasi adalah teknik pengumpulan data dengan cara mengamati dan mencatat secara sistematik unsur-unsur yang tampak dalam suatu objek penelitian (Nawawi dan Martini dalam Afifuddin dan Saebani, 2012). Observasi yang dilakukan oleh peneliti dalam penelitian ini adalah observasi pada pelaksanaan pelatihan pembuatan souvenir di LPK Ratih;

Wawancara adalah teknik pengumpulan data dengan cara menanyakan sesuatu kepada seseorang yang menjadi informan dengan bercakap-cakap secara tatap muka (Afifuddin dan Saebani, 2012). Dalam teknik pengumpulan data ini, peneliti mewawancarai semua pihak yang terkait baik itu pembuat program kegiatan, pelaksana program kegiatan maupun penerima manfaat program kegiatan;

Dokumentasi adalah teknik pengumpulan data dengan cara mencari bukti-bukti dari sumber nonmanusia terkait dengan objek yang diteliti (Afifuddin dan Saebani, 2012) yang berupa tulisan, gambar, atau karya-karya monumental dari seseorang (Sugiyono, 2013). Dalam penelitian ini yang peneliti dokumentasikan adalah pelaksanaan wawancara pada informan dan hasil dari keterampilan pembuatan souvenir.

\section{Teknik Analaisa Data}

Dalam penelitian ini peneliti menggunakan teknik analisis data model Miles dan Huberman. Miles dan Huberman dalam (Muri Yusuf, 2017) menegaskan, bahwa dalam penelitian kualitatif data yang terkumpul melalui berbagai teknik pengumpulan data yang berbeda-beda, seperti interviu, observasi, kutipan, dan sari dari dokumen, catatan-catatan melalui tape; terlihat lebih banyak berupa kata-kata daripada angka. Oleh karena itu, data tersebut harus "diproses" dan dianalisis sebelum dapat digunakan. Miles dan Huberman menawarkan pola umum analisis dengan mengikuti model air sebagai berikut:

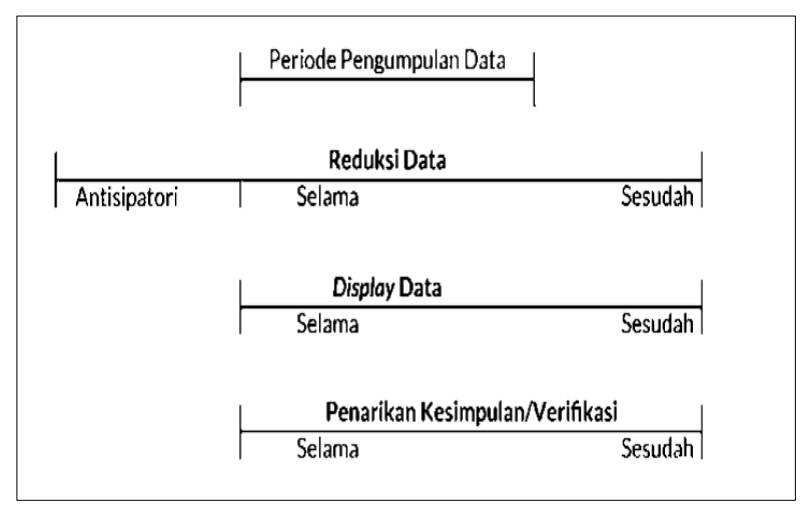

Dalam kerangka model air tersebut, peneliti melakukan tiga kegiatan analisis data secara serempak, yaitu:

\section{Reduksi data (data reduction)}

Menunjuk kepada proses pemilihan, pemokusan, penyederhanaan, pemisahan, dan pentransformasian data "mentah" yang terlihat dalam catatan tertulis lapangan (written-up field notes). Reduksi data adalah suatu bentuk analisis yang mempertajam, memilih, memfokuskan, membuang, dan mengorganisasikan data dalam satu cara, dimana kesimpulan akhir dapat digambarkan dan diverifikasikan.

\section{Data Display (Display data)}

Dalam konteks ini adalah kumpulan informasi yang telah tersusun yang membolehkan penarikan kesimpulan dan pengambilan tindakan. Bentuk display data dalam penelitian kualitatif yang paling sering yaitu teks naratif dan kejadian atau peristiwa itu terjadi di masa lampau. 


\section{Verifikasi}

Pada waktu penarikan kesimpulan atau verifikasi selalu bersumber dari reduksi data atau data yang sudah direduksi dan juga dari display data. Kesimpulan yang dibuat bukan sekali jadi. Kesimpulan menuntuk verifikasi oleh orang lain yang ahli dalam bidang yang diteliti, atau mungkin juga mengecek dengan data lain.

\section{HASIL DAN PEMBAHASAN}

Program kegiatan pelatihan keterampilan berbasis masyarakat (KK Miskin) merupakan salah satu kegiatan pelatihan keterampilan yang dilaksanakan sejak tahun 2015 dan masih berjalan hingga saat ini. Kegiatan ini lebih menekankan pada basis masyarakat dan berdasarkan aspirasi masyarakat. Tujuan dari dilaksanakannya kegiatan ini adalah memberikan keterampilan agar dapat berwirausaha dan menambah penghasilan bagi keluarganya. Dimana sasaran dari kegiatan ini adalah ibu rumah tangga maupun kepala keluarga yang sudah tidak bisa diserap oleh pasar kerja. Adapun analisis hasil data wawancara secara menyeluruh mengenai efektivitas kegiatan pelatihan keterampilan berbasis masyarakat (kk miskin) Kota Bogor, yaitu:

\section{Tahap Pra Pelatihan}

Pada tahap ini kelurahan-kelurahan yang terlibat dengan kegiatan pelatihan keterampilan berbasis masyarakat (KK Miskin) mensosialisasikan kepada masyarakatnya terkait dengan kegiatan pelatihan. Dimana jenis pelatihan keterampilan yang diberikan adalah pelatihan pembuatan souvenir, pelatihan pangkas rambut dan pelatihan tata rias. Selain mensosialisasikan kegiatan pelatihan keterampilan tersebut, pihak kelurahan juga mensosialisasikan persyaratan atau kriteria peserta pelatihan yaitu: Fotocopy register KK miskin; Jenis kelamis dan batas usia; Fotocopy KTP. Sosialisasi yang disampaikan oleh pihak kelurahan kepada masyarakat telah merata. Sehingga pada tahap pra pelatihan ini bisa dikatakan sudah efektif.

\section{Tahap Pelatihan}

Pada tahapan ini keterlibatan peserta dan instruktur pelatihan merupakan hal yang vital. Selama tahap pelaksanaan pelatihan keterampilan ini dilaksanakan peserta dapat memahami materi pelatihan dengan baik tetapi masih adanya keterbatasan bahan baku seperti lem pada pelatihan keterampilan pembuatan souvenir dan keterbatasan waktu pelatihan keterampilan yang diberikan menjadi kendala tersendiri bagi peserta pelatihan. Sehingga tahap pelatihan dari segi bahan baku dan waktu belum efektif. Dari sembilan informan selaku peserta pelatihan yang telah peneliti wawancara terkait pemberian materi pelatihan keterampilan dapat diketahui bahwa pemberian materi pelatihan telah efektif. Hasil ini disimpulkan berdasarkan jawaban dari informan yang mengatakan bahwa para informan dapat memahami dan menerapkan materi yang telah diberikan. Selain itu penguasaan materi instruktur atau pelatih tentunya memberikan peran yang besar dalam menyampaikan materi kepada peserta pelatihan. Selain penguasaan materi, pengendalian emosi serta pemberian motivasi juga menjadi faktor lain yang membuat pemberian materi menjadi efektif dan dapat diterima atau dipahami oleh peserta pelatihan. Sehingga pada tahap pelatihan dilihat dari segi bahan baku, waktu, pemahaman peserta terhadap materi yang diberikan dan pemberian materi oleh instruktur dapat disimpulkan bahwa tahapan ini cukup efektif.

\section{Tahap Monitoring}

Tahap monitoring melibatkan pihak aparatur kelurahan khususnya bagian kemasyarakatan dan staf Dinas Tenaga Kerja dan Transmigrasi Kota Bogor bagian Pelatihan dan Kelembagaan Pelatihan. Selama kegiatan pelatihan keterampilan berlangsung perwakilan dari aparatur kelurahan tidak dapat mengawasi secara terus menerus. Hal ini disebabkan adanya tugas lain yang harus dilakukan. Akan tetapi staf dari Disnakertrans selalu mengawasi selama proses pelatihan keterampilan berlangsung. Pada tahap monitoring ini dapat dikatakan sudah efektif.

\section{Tahap Evaluasi}

Tahap evaluasi merupakan tahap akhir dari tahapan kegiatan pelatihan keterampilan berbasis masyarakat (KK Miskin). Dalam tahap ini dapat diketahui bahwa peserta pelatihan keterampilan yang telah menyelesaikan pelatihannya tidak banyak yang meneruskan keterampilan yang didapatkannya. Hal ini terbukti dari sembilan informan yang peneliti teliti, hanya ada dua orang yang masih meneruskan keterampilan yang didapat dengan cara memasarkan hasil karyanya. Sedangkan tujuh peserta lain tidak meneruskan dengan alasan masih kurangnya keterampilan yang 
dimiliki dan tidak adanya modal. Sehingga dapat dikatakan bahwa kegiatan pelatihan keterampilan berbasis masyarakat berbasis masyarakat (KK Miskin) oleh Dinas Tenaga Kerja dan Transmigrasi Kota Bogor masih belum efektif. Adapun analisisnya adalah sebagai berikut:

\section{Peserta pelatihan keterampilan pembuatan souvenir}

Dari tiga informan peserta pelatihan keterampilan pembuatan souvenir hanya satu peserta yang memasarkan hasil pembuatan souvenir berupa bros setelah pelatihan keterampilan diberikan. Salah saru peserta pelatihan tersebut adalah ibu Titik yang berasal dari kelurahan Rancamaya. Ibu Titik memasarkan hasil karyanya berbarengan dengan mengantar anaknya ke sekolah. Pekerjaan utama ibu Titik sendiri adalah ibu rumah tangga sedangkan penjualan bros tersebut hanya sebagai sampingan. Hal ini karena keterbatasannya modal dan pengetahuan berkreasi dalam pembuatan model bros.

Sedangkan untuk dua informan lainnya yaitu, ibu Juriah yang berasal dari kelurahan Cibuluh dan ibu Nanih yang berasal dari kelurahan Rancamaya tidak meneruskan keterampilan yang didapat sebagai usaha pokok maupun sampingan. Adapun alasan yang diberikan oleh ibu Juriah adalah tidak adanya modal awal dan kurangnya peminat, selain itu juga pekerjaan ibu Juriah sebagai pengajar PAUD membuat waktu pembuatan souvenir menjadi tidak ada.

Alasan lainnya yang disampaikan oleh ibu Nanih adalah kondisinya yang saat ini tengah hamil dan sudah tidak aktifnya kelompok pembuat souvenir peserta pelatihan keterampilan yang telah lulus. Ketidakaktifan kelompok tersebut membuat modal yang harus dikeluarkan lebih banyak karena awalnya ketika kelompok tersebut masih aktif, para anggota akan membagi tiap-tiap keperluan yang diperlukan dalam pembuatan souvenir. Adapun pekerjaan ibu Nanih saat ini adalah sebagai buruh cuci.

\section{Peserta pelatihan pangkas rambut}

Dari tiga informan peserta pelatihan pangkas rambut tidak ada yang meneruskan keterampilan yang didapatkan sebagai pekerjaan utama maupun sampingan setelah pelatihan selesai. Tiga informan tersebut adalah bapak Ismat dari kelurahan Tegal Gundil, bapak Supardi dari kelurahan Tajur dan bapak Andre dari kelurahan Sukasari. Alasan yang diberikan oleh bapak Ismat adalah masih kurangnya keterampilan yang diberikan selama pelatihan jika ingin diteruskan sebagai pekerjaan pokok maupun sampingan. Selain itu tidak adanya modal dalam membeli perlengkapan barbershop membuat pak Ismat tidak dapat meneruskan keterampilan yang didapatkan. Karena perlengkapan yang diberikan pada saat pelatihan hanya sekedar untuk memotong rambut saja. Pekerjaan pak Ismat sendiri adalah wirausaha. Beliau membuka warung untuk berjualan.

Bapak Supardi sendiri memiliki alasan yang hampir serupa dengan pak Ismat. Tidak adanya kelanjutan dari pelatihan keterampilan dan terbenturnya modal menjadi alasan pak Supardi tidak menekuni keterampilan yang didapat sebagai usaha pokok maupun usaha sampingan. Pekerjaan pokok pak Supardi saat ini adalah seorang buruh.

Informan terakhir adalah bapak Andre yang juga memiliki alasan yang sama yaitu terkait dengan modal dan tempat untuk membuka usaha. Pekerjaan pak Andre saat ini adalah seorang office boy di RS. AZRA Bogor.

\section{Peserta pelatihan tata rias}

Dikatakan cukup efektif. Hal ini karena satu dari tiga informan yang peneliti teliti berhasil berwirausaha dengan keterampilan yang diberikan melalui pelatihan keterampilan berbasis masyarakat (KK Miskin). Informan tersebut adalah ibu Yuli yang telah membuka tempat tata riasnya dan berhasil menambah pemasukan dari usahanya tersebut. Sedangkan untuk dua informan lainnya seperti ibu Resna tidak meneruskan keterampilan yang diberikan dan lebih memilih menjadi ibu rumah tangga biasa. Untuk informan terakhir yakni ibu Rahma yang saat ini bekerja sebagai penjual es tidak meneruskan keterampilan yang diterima karena tidak memiliki modal.

Pada penelitian ini, penulis mengambil dua penelitian terdahulu sebagai pembanding dari penelitian yang saat ini penulis teliti adalah sebagai berikut: Dalam skripsi (Joko Legowo, 2009) Universitas Negeri Semarang dengan judul Peran Balai Pelatihan Kerja Industri Tenaga Kerja dan Transmigrasi Propinsi Jawa Tengah Dalam Rangka Pelaksanaan Kebijakan Peningkatan Kualitas Keterampilan Tenaga Kerja Indonesia; Persamaan a dapun yang menjadi persamaan dari penelitian Joko Legowo dengan yang peneliti teliti yaitu, pada metode penelitian yang digunakan. Dalam penelitiannya, Joko Legowo dan peneliti sama-sama menggunakan metode 
penelitian kualitatif yang hanya memiliki satu variable; Perbedaan Yang menjadi perbedaan dalam penelitian Joko Legowo dengan penelitian yang saat ini peneliti teliti adalah fokus penelitian. Dalam penelitiannya, Joko Legowo memfokuskan pada peningkatan kualitas keterampilan tenaga kerja Indonesia. Dengan menggunakan tenaga kerja Indonesia sebagai informannya. Sedangkan peneliti memfokuskan pada efektivitas pelaksanaan pelatihan keterampilan. Dengan menggunakan masyarakat miskin yang ikut dalam pelatihan sebagai informannya.

Selain itu lokus penelitian Joko Legowo dengan peneliti juga berbeda. Dimana Joko Legowo mengambil Balai Latihan Kerja Dinas Tenaga Kerja dan Transmigrasi Kota Semarang sebagai lokusnya. Sedangkan peneliti mengambil bidang Pelatihan dan Kelembagaan Pelatihan Dinas Tenaga Kerja dan Transmigrasi Kota Bogor. Dalam skripsi (Deka Arlita,2007) Universitas Sebelas Maret dengan judul Efektivitas Pelaksanaan Pelatihan Kerja di Unit Pelaksanaan Teknis Dinas Loka Latihan Kerja Usaha Kecil dan Menengah (UPTD LLK UKM) Wonogiri.

Persamaan adapun yang menjadi persamaan dari penelitian Deka Arlita dengan yang penelitian yang digunakan. Dalam penelitiannya, Deka Arlita dan peneliti sama-sama menggunakan metode penelitian kualitatif yang hanya memiliki satu variable.

Perbedaan yang menjadi perbedaan dalam penelitian Deka Arlita dengan penelitian yang saat ini peneliti teliti adalah fokus penelitian. Dalam penelitiannya, Deka Arlita memfokuskan pada pelatihan yang berbasis kompetensi. Sedangkan peneliti memfokuskan pada pelatihan yang berbasis masyarakat miskin. Selain itu lokus penelitian Deka Arlita dengan peneliti juga berbeda. Dimana Deka Arlita mengambil Dinas Loka Latihan Kerja Usaha Kecil dan Menengah (UPTD LLK UKM) Wonogiri sebagai lokusnya. Sedangkan peneliti mengambil bidang Pelatihan dan Kelembagaan Pelatihan Dinas Tenaga Kerja dan Transmigrasi Kota Bogor.

Dalam penelitian ini yang termasuk dalam faktor yang kuat dan lemah berdasarkan hasil penelitian adalah sebagai berikut: Faktor kekuatan Adapun faktor yang kuat dalam menentukan efektivitas pelaksanaan kegiatan pelatihan keterampilan berbasis masyarakat (kk miskin) adalah kecakapan instruktur dalam memberikan materi pelatihan, sarana dan pra sarana yang telah disediakan (bahan baku, atk, ruang pelatihan dan uang) dan sosialisasi yang merata dari kelurahan kepada masyarakat terkait adanya pelatihan; Faktor Kelemahan Faktor yang lemah dalam menentukan efektivitas pelaksanaan pelatihan keterampilan berbasis masyarakat (kk miskin) adalah tidak adanya kejelasan terkait adanya pelatihan keterampilan lanjutan, partisipasi masyarakat saat akan diadakan pelatihan dan pasar kerja yang kurang mendukung karena terbentur modal.

Dari hasil empat tahapan pelaksanaan pelatihan keterampilan yang penulis rangkum dalam tujuan yaitu tahap pra pelatihan, pelatihan, monitoring dan evaluasi dapat diketahui bahwa pelaksanaan kegiatan pelatihan keterampilan berbasis masyarakat (KK Miskin) tahun 2017 oleh Disnakertrans cukup efektif. Hal ini karena pada tahap pra pelatihan dan tahap pelatihan sudah efektif. Sedangkan pada tahap monitoring cukup efektif dan terakhir tahap evaluasi belum efektif.

\section{KESIMPULAN DAN IMPLIKASI}

\section{Kesimpulan}

Kegiatan pelatihan keterampilan berbasis masyarakat (KK Miskin) oleh Dinas Tenaga Kerja dan Transmigrasi Kota Bogor memiliki tujuan memberikan keterampilan agar peserta dapat berwirausaha dan menambah penghasilan bagi keluarganya. Sasaran dari kegiatan ini adalah ibu rumah tangga maupun kepala keluarga yang sudah tidak bisa diserap oleh pasar kerja. Efektivitas pemberian materi pelatihan dari sembilan informan selaku peserta pelatihan yang telah peneliti wawancara terkait pemberian materi pelatihan keterampilan dapat diketahui bahwa pemberian materi pelatihan telah efektif. Hal ini karena peserta pelatihan keterampilan dapat memahami materi yang diberikan oleh instruktur dengan baik.

Menjelaskan waktu pemberian materi pelatihan Bedasarkan hasil analisis dari wawancara yang telah dilakukan terkait waktu pemberian materi pelatihan adalah belum efektif. Belum efektifnya waktu pemberian materi pelatihan ini berkaitan dengan terbatasnya jam belajar pelatihan dan singkatnya waktu pelatihan diselenggarakan. Menganalisis materi pelatihan keterampilan dengan pekerjaan yang dimiliki Analisis dari materi pelatihan keterampilan pembuatan souvenir, pangkas rambut, dan tata rias dengan pekerjaan yang dimiliki peserta pelatihan keterampilan masih belum efektif. Kesimpulan ini didapatkan berdasarkan jumlah informan yang meneruskan keterampilan yang diterima sebagai pekerjaannya saat ini. 


\section{Implikasi}

Alat ukur dalam mengukur efektivitas kegiatan pelatihan keterampilan berbasis masyarakat (KK Miskin) dalam penelitian ini menggunakan teori yang dikemukakan oleh Stoner (dalam Hassel). Maka dari itu hasil dari penelitian ini didasarkan pada perspektif tujuan. Dimana tolak ukur yang digunakan adalah bagaimana organisasi mencapai tujuan, termasuk merealisasi visi dan misi sesuai dengan mandat yang diembannya. Perspektif tujuan tersebut sudah tepat digunakan dalam penelitian efektivitas kegiatan pelatihan keterampilan berbasis masyarakat (KK Miskin) tahun 2017 oleh Dinas Tenaga Kerta dan Transmigrasi Kota Bogor. Perspektif tujuan ini kemudian dikaitkan dengan tahapan pelatihan keterampilan yaitu, tahap pra pelatihan, pelatihan, monitoring dan evaluasi.

Adapun implikasi praktis dalam efektivitas kegiatan pelatihan keterampilan berbasis masyarakat (KK Miskin) oleh Dinas Tenaga Kerja dan Transmigrasi Kota Bogor ini berkaitan erat dengan hasil penelitian. Dimana dari hasil penelitian itu diketahui bahwa kegiatan pelatihan keterampilan berbasis masyarakat (KK Miskin) memiliki empat tahap. Pada tahap pertama terdapat tahap pra pelatihan yang didalamnya dimulai dari sosialisasi tentang kegiatan pelatihan ketepampilan kepada masyarakat beserta persyaratan atau kriterianya. Tahap selanjutnya adalah pelaksanaan pelatihan, monitoring dan evaluasi.

\section{DAFTAR PUSTAKA}

\section{Buku}

Barthos, Basir. (2001) Manajemen Sumber Daya Manusia suatu pendekatan makro. Bumi Aksara, Jakarta.

Handoko, T Hani. (2000) Manajemen Personalia dan Sumber Daya Manusia Edisi Kedua. BPFE, Yogyakarta.

Hasibuan, Malayu. (2017) Manajemen Sumber Daya Edisi Revisi. PT Bumi Aksara, Jakarta.

Santoso, Budi. (2013) Skema dan Mekanisme Pelatihan: Panduan Penyelenggaraan Palatihan. Yayasan Terumbu Karang Indonesia (TERANGI), Jakarta.
Sugiarto, Eko. (2015) Menyusun Proposal Penelitian Kualitatif: Skripsi dan Tesis. Suaka Media,Yogyakarta.

Sugiyono. (2010) Metode Penelitian Pendidikan Pendekatan Kuantitatif, Kualitatif, dan R\&D. Alfabeta, Bandung. .. (2011) Metode Penelitian Pendidikan Pendekatan Kuantitatif, Kualitatif, dan R\&D. Alfabeta, Bandung. .. (2013) Metode Penelitian Pendidikan Pendekatan Kuantitatif, Kualitatif, dan R\&D. Alfabeta, Bandung.

Tangkilisan, Nogi Hassel. (2005) Manajemen Publik. PT. Gramedia Widiasarana Indonesia, Jakarta.

Yusuf, Muri. (2017) Metode Penelitian: Kuantitatif, Kualitatif, Dan Penelitian Gabungan Edisi Pertama. KENCANA, Jakarta.

\section{Dokumen dan Karya Ilmiah}

Arlita Sari, Deka. (2007) Efektivitas Pelaksanaan Pelatihan Kerja di Unit Pelaksana Teknis Dinas Loka Latihan Kerja Usaha Kecil Dan Menengah (UPTD LLK UKM) Wonogiri. Universitas Sebelas Maret, Surakarta.

BPS, Katalog. 2017. Kecamatan Bogor Tengah Dalam Angka Bogor Tengah Subdistrict in Figures 2017. Bogor: BPS Kota Bogor.

BPS, Katalog. 2017. Kecamatan Bogor Utara Dalam Angka Bogor Utara Subdistrict in Figures 2017. Bogor: BPS Kota Bogor.

BPS, Katalog. 2017. Kecamatan Bogor Barat Dalam Angka Bogor Barat Subdistrict in Figures 2017. Bogor: BPS Kota Bogor.

BPS, Katalog. 2017. Kecamatan Bogor Selatan Dalam Angka Bogor Selatan Subdistrict in Figures 2017. Bogor: BPS Kota Bogor.

BPS, Katalog. 2017. Kecamatan Bogor Timur Dalam Angka Bogor Timur Subdistrict in Figures 2017. Bogor: BPS Kota Bogor.

BPS, Katalog. 2017. Kecamatan Tanah Sareal Dalam Angka Tanah Sareal Subdistrict in Figures 2017. Bogor: BPS Kota Bogor.

Ishatono \& Santoso Tri Raharjo. (2016) Sustainable Development Goals (SDGs) dan Pengentasan Kemiskinan . Vol. 6 Nomor 2. Social Wark Jurnal.

Jadwal Kegiatan Pelatihan Keterampilan Bebasis Masyarakat ( KK Miskin) Tahun 2017 Dinas Tenaga Kerja dan Transmigrasi Kota Bogor. Kota Bogor dalam Angka Tahun 2017.

Legowo, Joko. (2009) Peran Balai Latihan Kerja Industri Dinas Tenaga Kerja dan 
Transmigrasi Propinsi Jawa Tengah Dalam Rangka Pelaksanaan Kebijakan Peningkatan Kualitas Keterampilan Tenaga Kerja Indonesia. Universita Negeri Semarang, Semarang.

Lityaui. (2014) Pengaruh Motivasi Pelatihan dan Job Analis terhadap Kinerja Karyawan PT. Warni Indah Cemerlang. Vol. 1 Nomor 2. Jurnal JOM FEKON.

\section{Website atau Internet}

www.bogorkota.bps.go.id diakses pada tanggal 22 November 2017.

http://sdgsindonesia.or.id diakses pada tanggal 10 Juli 2018. 